\title{
Growth Performance, Carcass Characteristics, Lipid Profiles And Hematological Responses Of Broiler Finishers Fed With Leaf Meals Derived From 'Ntong' (Ocimumgratissimum) And 'Utasi' (Gongronemalatifolium)'
}

\author{
${ }^{1,}$ Essiet, Akanimo Gordon And ${ }^{2,}$ Solomon, Isongesit P. \\ ${ }^{1,2,(D e p a r t m e n t ~ o f ~ A n i m a l ~ S c i e n c e, ~ F a c u l t y ~ o f ~ A g r i c u l t u r e, ~ U n i v e r s i t y ~ o f ~ U y o, ~ N i g e r i a) ~}$
}

\begin{abstract}
There is a need to identify new sources of poultry fodder in order to meet the growing demand for animal protein in the developing world. To this end, experiments were conducted to determine how the inclusion of Ocimumgratissimum ("Ntong") and Gongronemalatifolium ("Utasi") leaf meals in the diets of broiler finishers affect the birds' growth performance, carcass characteristics, hematological indices and lipid profiles. Fresh leaves of the two plant species were dried and pulverized and then mixed with conventional feeds in various proportions to produce seven experimental diets that were fed to groups of broiler finishers. The chemical composition of each diet was determined by proximate analysis. Diet 1 (the control) contained no leaf meal (0\%); diets 2, 3 and 4 contained 1\%, 6\% and 11\% Ocimum Leaf Meal (OLM), respectively; and diets 5, 6 and 7 contained 1\%, 6\%, and 11\% Gongronema leaf Meal (GLM), respectively The feed intakes of the control and treatment groups $(120.3 \mathrm{~g}, 120.8 \mathrm{~g}, 120.43 \mathrm{~g}, 114.2 \mathrm{~g}, 120.1 \mathrm{~g}, 119.0 \mathrm{~g}$ and $117.2 \mathrm{~g} / \mathrm{day})$ did not differ significantly ( $p>0.05)$. However, the body weights of the birds in different treatment groups did $(p<0.05)$. Notably, birds consuming the 1\% OLM (1683.0g) and 11\% GLM (1716.6g) diets had lower final weights than did birds in the control group. In addition, there were significant differences $(p<0.05)$ between the treatment groups with respect to carcass characteristics. The blood indices and lipid profiles of the studied birds were significantly $(p<0.05)$ affected by the inclusion of the leaf meals, although the values of the hematological indices were generally low. These results suggest that Ocimumgratissimum and Gongronemalatifolium leaf meals have considerable potential as supplementary components of broiler finisher diets in developing countries but further investigations will be required to determine the optimal level of inclusion for these meals, to identify the bioactive compounds they contain, and to develop appropriate detoxification procedures to mitigate their potential adverse effects on growth performance.
\end{abstract}

KEY WORDS:Arteriosclerosis, Cholesterolaemia, Ocimumgratissimum, Gongronemalatifolium, Lipidaemia

\section{INTRODUCTION}

There are strong correlations between indices of national or regional development and the contribution of poultry to the supply of animal protein within a country or region. It is therefore desirable to increase the production and consumption of poultry in developing countries. In recent years, the cost of poultry feed resources in Nigeria has risen to the point that feed now accounts for $75-80 \%$ of the entire cost of poultry production (Ugochukwu and Babady, 2002). Feed ingredients are very expensive and so in order to sustain rapid increases in poultry production, corresponding increases in the production of poultry feed will be required. However, there is a growing demand for feed resources and the cost of conventional feed ingredients (soybean and groundnut cake) is rising due to competition between the production of livestock meal and food for human consumption. As a consequence, there is growing interest in the production of leaf meals for livestock consumption from currently under-utilized vegetables and leguminous plants (Okaforet al., 1996). The demand for animal protein in Nigeria will have to be met by the cultivation of many different livestock species. Despite the country's large populations of chickens and other livestock animals, it will be challenging to provide an adequate supply of protein for its rapidly growing human population, as is the case in many developing countries (Ayodele and Agboola, 1983; Okafor et al., 1996; Umohet al., 2003). Improvements in the quantity and quality of the feeds available to the country's poultry industry will therefore be important. 
As discussed by Adebayo et al., (2004), Nigeria is endowed with many indigenous species of leafy vegetables, which are cultivated on an estimated 71.2 million hectares of agricultural land. The potential of the Nigerian flora as a valuable source of pharmaceuticals and therapeutic materials has been emphasized (Gbile and Adesina, 1998).Tropical shrubs and leguminous vegetables can be used to produce leaf meals that contain appreciable quantities of biologically active compounds such as tannins, saponins, and phytins. These compounds affect the palatability, intake and digestibility of the meal. Oji and Isilebo (2000) studied the chemical properties of some of these meals and found them to be rich in crude fibre and minerals, both of which can reduce the utility of potential feeds.

However, they are attractive because of their high protein contents. The search for cheaper sources of protein that will be available all year round has led to the consideration of leaf meals derived from Ocimumgratissimum and Gongronemalatifoliumas poultry feeds.In order to improve the productivity of an animal by changing its feedstuff, one must understand its physiological responses, and especially its hematological responses, to the diets under consideration. Hematological changes reflect the animal's physiological responses to changes in its external and internal environments (Okeudoet al., 2003). Anderson nd Warnick, (1989) have demonstrated the effectiveness of vegetables and indigenous leaf meals at reducing serum cholesterol in hypercholesterolemic humans. Although some of these leaf meals are high in protein and rich in minerals (Adeboyeet al., 2003a), some of them contain anti-nutritional or toxic compounds. However, if these compounds can be removed, the resulting meals may be very good sources of plant protein that could serve as excellent animal feeds.

\section{OBJECTIVES}

1. To evaluate the effects of feeding with leaf meals derived from Ocimumgratissimum and Gongronemalatifoliumon the body weight dynamics of broiler finishers.

2. To evaluate the toxicological consequences of consuming these leaf meals (Ocimumgratissimum and Gongronemalatifolium) in terms of the birds' hematological indices and lipid profiles.

\section{MATERIALS AND METHODS}

\section{Experimental site}

The experiment was carried out in the poultry unit of the Teaching / Research farm and the Animal Science laboratory of the University of Uyo, Uyo, Akwalbom state, Nigeria.

\section{Care of experimental animals}

Two hundred and sixty broiler chicks were purchased from a local dealer who maintains a facility on IkotEkpene Road in Uyo. The birds were raised in a deep litter system for 4 weeks prior to the commencement of the feeding trial.Before the birds' arrival, the brooding house was thoroughly cleaned with diesel mixed with kerosene and detergent. It was then fumigated with crystalline potassium permanganate and $50 \%$ formaldehyde. This was done to curb the incidence of coccidiosis, which had become endemic within the farm. The tray feeders and drinkers in the brooding house were then washed and disinfected, and wood shavings were spread adequately on the floor of the pen. Electric heaters and lights were the primary sources of heat and light; stoves were used for supplementary heating during colder periods. Black polythene sheets were used to cover the sides of the brooding house to conserve heat.On arrival, the birds were transferred from their boxes to the floor, where paper with feed spread on it had already been set up. Water containing anti-stress agents was also provided. Other management procedures were strictly followed.

\section{Procurement and processing of leaf meals}

The test materials - Ntong (Ocimum) and Utasi (Gongronema) leaves - were harvested fresh from the region surrounding Abak or purchased from market stalls in Abak, Akwalbom state, Nigeria. The leaves were chopped to expedite their drying and sun-dried for 4 days. The sun-dried leaves were then oven-dried at $102{ }^{\circ} \mathrm{C}$ until they became crispy while retaining their greenish-brown color. The dried leaves were then pulverized using a laboratory blender. Samples of each leaf meal were subjected to proximate analysis using the protocols described by the AOAC (1999).

\section{The experimental diets}

Seven experimental broiler finisher diets were formulated. The first was a conventional diet that consisted of soybean meal, groundnut cake, and wheat offal; this was used as a control. Three of the formulated diets used the conventional diet as a base but replaced $1 \%, 6 \%$, or $11 \%$ of the material (by mass) with Ntong (Ocimumgratissimum) leaf meal (OLM). 
The other three diets replaced $1 \%, 6 \%$, or $11 \%$ of the material from the conventional diet (by mass) with Utasi (Gongronemalatifolium) leaf meal (GLM). Table 1 shows the proximate composition data for the leaf meals, while Table 2 shows the compositions of the diets.

\section{Experimental birds and the design of the experiment}

Two hundred and fifty-two four-week-old broiler finisher birds were divided into 7 groups and randomly assigned to the 7 dietary treatments in a completely randomized design (CRD). Each dietary group was further divided into three replicates of 12 birds. Food and water were provided on a free choice basis on the first two days to facilitate acclimatization and were replaced daily thereafter. The birds were weighed at the beginning of the $5^{\text {th }}$ week to determine their 'initial' weights and weekly thereafter. Their feed intake was recorded on a daily basis by subtracting the weight of the leftover feed from the weight of feed offered.

\section{Data collection}

The initial body weight measurements were used to compute the birds' total weight gain over the experimental period. The following variables were monitored: initial body weight, final body weight, feed intake and feed conversion ratio. Feed intake was calculated on a daily basis by subtracting the weight of the leftover feed from the weight of the feed offered on the previous day. At the end of the $9^{\text {th }}$ week, three birds were randomly selected from each of the treatment groups, deprived of feed (but not water for 12 hours), slaughtered by brachial bone dislocation, and eviscerated for carcass weight determination.

\section{Collection of blood samples}

On the $35^{\text {th }}$ day of the experiment, blood samples were collected from three birds in each treatment group by brachial vein puncture. The sub-clavicle vein was punctured with a $5 \mathrm{ml}$ vein needle and blood was extracted into a set of sterilized glass tubes containing EDTA (ethylenediamine tetra acetic acid) for use in the determination of the following hematological parameters: hemoglobin content $(\mathrm{Hb})$, packed cell volume (PCV), white blood cell (WBC) count, mean corpuscular hemoglobin concentration (MCHC), neutrophil content, lymphocyte content, eosinophil content, basophil content, and monocyte content. The hemoglobin (Hb) concentration was estimated by centrifuging the blood samples to separate the cells. The volume of the red region was measured and recorded as the packed cell volume (PCV); the hemoglobin content was assumed to be equal to $33 \%$ of the PCV (Cheesbrough, 1987).

White blood cell counts were determined by acidic lysis and staining. A light microscope was used to count the stained cells, and the WBC was calculated using the following expression:

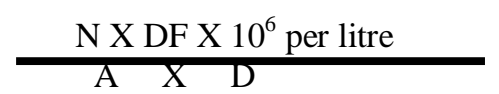

Where $\mathrm{N}=$ the number of cells

$\mathrm{DF}=$ dilution factor

$10^{6}=$ converts to cell/litre

A $=$ the area of chamber counted

$\mathrm{D}=$ the depth of chamber

A second set of serum samples was stored in glass tubes without added anticoagulant and used for serum lipid profiling, which involved measuring their total cholesterol, very low density lipoprotein, low density lipoprotein, high density lipoprotein, and triglyceride contents. Samples were prepared for lipid analysis by centrifugation at $200 \mathrm{~g}$ and then stored in a deep freezer prior to analysis.

\section{Carcass evaluation}

Prior to brachial bone dislocation, 2 sets of water baths were prepared. As soon as the birds were certified dead, they were immersed in steaming water for less than two minutes to facilitate defeathering. The carcasses were then eviscerated, starting from the neck via the head. The different parts of the carcass (thigh and drum sticks, wing, shank, and breast region) were carefully removed, followed by the organs (spleen, gizzard, heart, liver and gall bladder). The individual parts and organs were then weighed.

\section{Evaluation of performance characteristics: feed utilization}

At the beginning of each new day, a fixed quantity of feed was weighed out into a labeled container for each replicate group. The leftover feed was weighed on the morning of the following day to determine each group's feed consumption for that day. Feed conversion ratios were then calculated using the following expression:

$$
\text { Feed conversion ratio }=\quad \text { Feed intake }
$$




\section{Evaluation of performance characteristics: body weight}

Weight gain

The average weight gain of birds in each week was measured by calculating the difference between the mean weights for successive weeks.

Evaluation of performance characteristics: feed efficiency (FE)

Feed efficiency was calculated using the feed intake and weight gain measurements:

$\mathrm{FE}=$ Body weight gain $(\mathrm{g}) \quad \mathrm{x} \quad 100$

1

Feed intake $(\mathrm{g})$

\section{Analytical procedure}

The packed cell volume (PCV) was determined using the Wintrobemicrohematocrit method (Agale and Uko, 1989). Red blood cell (RBC) and white blood cell (WBC) counts were obtained using an improved Neubaerhemocytometer and the cyanomethemoglobin method, respectively, after dilution as described by Okeudoet al. (2003). The mean corpuscular hemoglobin concentration (MCHC) was computed using the method of Jain (1986), which involves dividing the Hb value by the PCV value (Onyeyili et al., 1992).

\section{Data analysis}

The data obtained from this study were subjected to one way analysis of variance (ANOVA) (Steel and Torrie, 1980). Duncan's multiple range test was used to identify significant difference between mean values, as described by Snedecor and Cochran (1978)

\section{RESULTS}

Proximate analysis data are used extensively in industrial research in order to obtain a quick overview of the nutrient potentials of feedstuffs. While such analyses may not give a completely accurate indication of a feed's nutritional merits, they provide information that is useful when determining whether a prospective feedstuff has enough potential to justify further studiesin vitro or in vivo.Table 3 shows the calculated chemical compositions of the experimental diets examined in this work. The crude protein contents for all of the diets are within the ranges identified as being optimal by Reynolds and Attakrah. (1987). Their crude fiber contents range from $4.68(0 \%)$ to $4.94(11 \%$ OLM). Indigenous plants have been shown to have higher crude fiber contents than exotic species when grown in the acidic soils of tropical regions (Ndon and Essien, 1987). The caloric values estimated for each diet based on their chemical compositions are similar to those reported by D'Mello (1992) and Igile et al. (1986). However, the crude protein contents of the diets are somewhat higher than might be expected based on previous results; this may be due to differences between the plant species involved or to the properties of the environments in which they were cultivated.

\section{Feed intake and body weight gain}

Table 4 shows the growth performance of the experimental birds in terms of their mean daily weight gain, daily intake, feed efficiency and feed conversion ratios for the various studied diets. The data cover the birds' $5^{\text {th }}$ to $9^{\text {th }}$ weeks of life.The average feed intakes for the control, $1 \%$ OLM, 6\% OLM, $11 \%$ OLM, $1 \%$ GLM, 6\% GLM and 11\% GLM diets were 120.3, 120.8, 120.4, 114.2, 120.10, 119.8 and $117.02 \mathrm{~g} /$ day, respectively. There were no significant $(\mathrm{P}>0.05)$ differences between the treatments with respect to this variable, so the inclusion of the leaf meals (Ocimumand Gongronema) did not affect the birds' feed intakes. These results contradict the findings of Esonuet al. (2002), Ekenyem (2006), Herbert (1998), Onwudike, (1995), Udedibie and Opara (1998) and Mishra et al. (1977), all of whom reported that the inclusion of materials derived from Ocimumor Gongronemain the diet significantly reduced feed intake. The difference between our findings and the previous results may be due to the lack of fibre in the Ocimumand Gongronemaleaf meals used in this work, since fibre can potentially inhibit feed intake. This would be consistent with the argument of Omekam (1994), who suggested that the low feed intakes seen in previous studies may have been due to the non-palatable nature of the feeds used.There were significant $(\mathrm{p}<0.05)$ differences between the diets with respect to the increase in body weight; the largest weight gain occurred for the $11 \%$ OLM diet, while the smallest gains were associated with the $1 \%$ GLM $(1130 \mathrm{~g})$ and $11 \%$ GLM $(1170 \mathrm{~g})$ diets. The increase in body weight correlated strongly with feed intake. These results indicate that the inclusion of Gongronemalatifolium leaf meal in the feed is deleterious to the growth performance of the finisher broilers. However, the inclusion of $11 \%$ (by mass) of Ocimumleaf meal had a positive effect on growth. This suggests that GLM may contain chemical compounds that disfavor growth.These results are consistent with those presented by Esonuet al. (2002). Udedibie and Opara (1998) and D'Mello and Acamovic (1989), who noted that growth starts to decline in birds consuming diets that contain large quantities of leaf meal 
They are also consistent with the observation of a dose-dependent reduction in growth as the quantity of leaf meal in the diet is increased, which was attributed to the low metabolisable energy content of leaf meals (D'Mello and Acamovic, 1989). In cases where the experimental diet is low in methionine or completely methionine deficient, this would be sufficient to explain poor growth performance. However, since all of the experimental diets considered in this work provided ample methionine, it is more likely that the poor performance observed for the $11 \%$ GLM diet was due to the presence of toxic compounds in the plant meal. Alternatively, it may be that the digestibility of the protein in the GLM meal is low. This hypothesis is consistent with the findings of Igileet al. (1994), whoobserved that mice fed on diets containing dry Vernoniaamygdalina leaves (25\% of the total diet by mass) gained less weight than did animals on a control diet, and that a near-identical reduction occurred in mice that were fed the control diet together with any one of (i) an alcohol extract of the $V$. amygdalina leaves, (ii) crude saponins from the $V$. amygdalinaleaves, or (iii) purified saponins from the $V$. amygdalina leaves. It should be noted that the GLM used in this trial is also rich in saponins.

\section{Feed conversion ratio (FCR)}

The feed conversion ratio did not differ significantly between groups $(\mathrm{P}>0.05)$, as shown in Table 4 , which suggests that increasing the proportion of Ocimumor Gongronemaleaf meal in the diet does not reduce the feed conversion ratios of finisher broilers. This finding is inconsistent with the report by Odunsiet al. (2002) that the feed conversion ratio decreases as the proportion of leaf meal in the feed increases. Similarly, Yu et al. (2007) reported decreased feed conversion ratios in animals offered leaf meal-based diets. However, other reports such as those produced by Oluyemi and Roberts (1979), Babatunde and Fetuga (1976), and Olomu and Offiong (1980) suggest that the Feed Conversion Ratio can be increased by incorporating leaf meals if the quality of the dietary protein is increased by doing so.

\section{Hematological indices}

Table 5 shows the hematological indices of birds consuming the 1\%, 6\%, and 11\% OLM and GLM diets. normal physiological function of $\mathrm{Hb}$ erythrocytes (RBCs) is to transport oxygen and carbon dioxide. The results presented in Table 5 are similar to those observed for animals consuming a saponin-containing diet (Takada et al., 1980). While the leaf meals used in this work were not analyzed for anti-feedants, the results suggest that anti-feedants in the OLM and GLM meals were released into the blood streams of the experimental birds and caused some level of systematic toxicity that reduced the birds' PCV, RBC and WBC values. This phenomenon was especially pronounced for the 6\% and 11\% OLM and GLM diets.

\section{Haemoglobin (Hb) concentration}

The hemoglobin $(\mathrm{Hb})$ concentrations for the control group, the $1 \%, 6 \%$, and $11 \%$ OLM groups, and the $1 \%, 6 \%$, and $11 \%$ GLM groups were $6.46,5.35,5.00,501,5.63,6.61$, and $5.33 \mathrm{~g} / \mathrm{dL}$, respectively. There were no significant $(\mathrm{P}>0.05)$ differences between the treatments groups, and none of the measured values were within the range identified as optimal by Lindsay (1977). Mitruka and Rawnsley (1977) identified Hb contents of 7 $18 \mathrm{~g} / \mathrm{dL}$ as being normal in chickens.

\section{Packed cell volume (PCV)}

The packed cell volumes for the control group, the $1 \%, 6 \%$, and $11 \%$ OLM groups, and the $1 \%, 6 \%$, and $11 \%$ GLM groups were $17.16 \%, 17.20 \%, 14.83 \%, 15.16 \%, 18.16 \%, 20.16 \%$ and $17.60 \%$, respectively. There was a strongly negative correlation $(r=-0.84)$ between the PCV and the feed intake. Interestingly, the $6 \%$ GLM group had a comparatively high packed cell volume compared to the other leaf meal diet groups. In addition, there were significant $(\mathrm{P}>0.05)$ differences between the treatment groups with respect to the PCV.

\section{White blood cell (WBC) count}

The white blood cell counts for the control group, the $1 \%, 6 \%$, and $11 \%$ OLM groups, and the $1 \%, 6 \%$, and $11 \%$ GLM groups were $3.60,4.60,4.50,4.00,5.30,4.30$ and $4.50 \times 10^{5}$, respectively. Although the WBC values obtained for the different treatment groups examined in this work differed significantly $(\mathrm{P}<0.05)$, they were all lower than those reported by Taiwoet al. (2002) and Ukoet al., (2000). The values obtained in this work were also below the range of normal values reported by Mitruka and Rawnsley (1977). These results may indicate that the leaf meal-containing diets mildly suppressed the birds' hematopoietic tissues and thereby reduced WBC production. Table 5 shows that the highest PCV value occurred in the 6\% GLM group while the lowest occurred in the 6\% OLM group. In addition, the highest MCHC value was observed for the 6\% OLM group (3.36) while the lowest occurred in the 0\% control group (3.01). 
There were no significant differences between the groups with respect to PCV ( $>0.05)$. In general, the hematological values for the various treatment groups were somewhat lower than those for the control group. A low hematocrit value reflects a low number of circulating RBC and therefore indicates a reduced oxygencarrying capacity or dehydration. The effects of the latter condition can be induced by the consumption of astringent compounds. The 6\% GLM diet produced the lowest feed efficiency (25.16) and the highest PCV value (20.16) of all the tested diets. This suggests that a high hematocrit is indicative of an excessively high intake of exogenous erythropoietin, which may stimulate an overproduction of RBC. On the other hand, high hematocrit values can also reflect an absolute increase in the number of erythrocytes $(\mathrm{Hb})$ or a decrease in plasma volume, as occurs in conditions such as severe dehydration, excessive RBC production, abnormal increases in blood cell abundance (polycthemia), or inherited disorders of iron metabolism (hemachromatosis). The latter of these conditions is extremely unlikely to have been a factor in the studied case, however.Lindsay (1977) reported that the values of hematological indices can fall gradually in animals on low protein diets (although this may be masked by the other biological effects of the diet) and in cases of parasitological infestations or liver damage. None of these factors could be ruled out in this case, since the quantities of bioactive compounds present in the different diets were not determined. Abnormal PCV and WBC values can be indicative of hemorrhaging and purulent inflammation, respectively. WBC values can also be increased by acute bacterial infections, neoplastic leukaemia, tissue necrosis, trauma, and chemical or metabolic intoxication. It is possible that the observed differences in WBC counts between the treatments may have been caused by pyrogenic bacterial infections, which are known to affect the abundance of neutrophils (polymorphonuclear leukocytes). The reduced neutrophil levels (relative to the control group) seen in birds consuming OLM- and GLM-containing diets could potentially be due to an elevated production of lymphocytes induced by immunological factors. Coles (1977) studied the immunological activity of lymphocytes in birds that had been exposed to foreign compounds and found that increases in the activity of transaminases in the liver and serum were indicative of liver damage. Elevated levels of monocytes and lymphocytes are associated with immune responses to antigens in chronic or healing inflammatory processes.

Eosinophil, basophil and neutrophil counts all rise during allergic responses and are frequently associated with helminth infections. The counts of all these cell types were very low in birds consuming the 6\% OLM, 6\% GLM, 11\% OLM and 11\% GLM diets, suggesting that the leaf extracts may have anti-helminthic properties. The relatively low RBC counts may reflect severe parasitism or malnutrition, both of which reduce the number of circulating RBCs and their hemoglobin content.

\section{Carcass evaluations}

The effect of including Ocimumgratissimumand Gongronemalatifoliumleaf meals in the diets of broiler chickens on the birds' carcass and organ weights are presented in Tables 6 and 8.

\section{Live weight}

The live weights of the slaughtered birds were $1.83,1.96,2.04,1.85,1.80$ and $1.72 \mathrm{~kg}$ for the control group, the $1 \%, 6 \%$, and $11 \%$ OLM groups, and the $1 \%, 6 \%$, and $11 \%$ GLM groups, respectively, as shown in Table 6 . There was a very weak positive correlation $(r=0.05)$ between feed intake and the live weights of the slaughtered birds. In addition, there were significant $(\mathrm{p}<0.05)$ differences between the treatments with respect to the final live weight.

\section{Dressed weight}

The dressed weights of the different treatment groups differed significantly $(\mathrm{p}<0.05)$, as shown in Table 7. The inclusion of the leaf meals (OLM and GLM) in the birds' diets thus had significant $(\mathrm{p}<0.05)$ effects on the birds' dressed weights.

\section{Other carcass weight ( $\%$ of dressed weight)}

The weights of the body parts for each group were calculated as percentages of the corresponding dressed weights, and are shown in Table 7. There were significant $(p<0.05)$ differences between the treatment groups with respect to the relative weights of the different body parts, and the data suggest that the leaf meals had positive effects on the carcass weights of the finisher broiler birds.

\section{Eviscerated organs (\% of dressed weight)}

The weights of the organs were also measured and expressed as percentages of the total dressed weight for each treatment, as shown in Table 8. 
There were no significant $(\mathrm{P}>0.05)$ differences between the treatment groups in terms of the relative masses of the organs with the exception of the livers, whose relative mass increased with the proportion of leaf meal in the diet. It is assumed that the significant differences in the masses of the livers of birds from different treatment groups were due to the toxicity of compounds in the different leaf meals. Atuaheneet al. (1986) and Bangbose and Niba (1998) found that birds consuming diets that contained high levels of raw cotton seeds had significantly heavier livers than did control birds, and attributed this to the presence of toxic compounds in the seeds. Overall, the data presented herein suggest that the scope for incorporating OLM and GLM into the diets of broiler finishers will depend on the development of processing techniques for removing toxic compounds from the leaf material, since these seem to be detrimental to the health of the birds. It should however be noted that none of the experimental birds died as a result of consuming any of the diets tested in this work. The diet that yielded the highest overall live weight was the 1\% GLM diet, while the lowest live weight occurred for the $1 \%$ OLM diet. The overall live weight gained in each case reflects the birds' abilities to convert their intakes into meaningful weight gain.

Lipid profiles :Lipids have very high energy densities. Consequently, they are valuable components of poultry diets. In addition, because of their high energy contents, diets that are rich in lipids can accommodate other less nutritionally valuable components without harming overall growth. This is of particular importance in economic terms because it may be desirable to include other dietary components in order to reduce feed costs or to increase the nutritional quality of the diet. Some lipids are essential fatty acids such as linoleic and arachidonic acid, both of which are important for the biosynthesis of phospholipids. Phospholipids in turn are important constituents of cell membranes and are essential for the formation of prostaglandins, which are involved in the regulation of various metabolic processes (Hurwitz et al., 1980). A variety of lipids are important in animal nutrition, including the triacylglycerols, which are produced by the triple esterification of glycerol with three fatty acid molecules. Jensen et al. (1997) showed that most lipids in poultry diets are digested by enzymes secreted by the pancreas. However, in younger animals, gastric lipase is capable of hydrolyzing lipids. Fats are insoluble in water and must therefore be emulsified prior to cleavage. This is achieved by the secretion of bile salts and phospholipids into the duodenum.

Many researchers have demonstrated that increases in dietary fat correlate closely with the secretion of lipases and levels of high density lipoprotein. (Coring et al., 1989). However, there is relatively little information regarding the effects of the quality of the dietary fat on the secretory activity of the pancreas, liver and other vital organs in monogastrics. It is known that hydroperoxides, which are the primary products resulting from the oxidation of unsaturated fats during storage and processing, are involved in the production of rancidity, odors, bad flavors and even toxic compounds (Ozimeket al., 1995a, b). In the 11\% GLM and OLM diets, almost $25 \%$ of the protein sources in the control diet were replaced with leaf meals. This caused a 2.5 -fold increase in the total lipid activity within the birds, with a particularly pronounced decrease in the levels of bad cholesterol (low-density lipoprotein). Table 9 shows the lipid profiles of broiler finisher birds fed on diets with different contents of the OLM (Ntong) and GLM (Utasi) leaf meals. In the absence of methionine deficiency, the reduced growth of birds on the OLM and GLM diets is probably caused by the presence of toxic compounds, protein sources of low digestibility, and above all compounds with hypocholesterolaemic activity.

The leaf meals examined in this work contain a range of bioactive components, including stigmastenetype steroidal saponins, tannins, phenolic compounds, alkaloids, and flavonoids. Compounds from these classes are known to have anti-feedant properties (Miller and Rains, 1963 and Igileet al., 1994).Our observations are consistent with the findings of Mishra et al. (1977), who reported a significant reduction in body weight gain for mice consuming standard diets containing similar anti-feedants. In this work, the birds consuming the leaf meal diets exhibited reduced values for various haematological parameters (particularly PCV and WBC counts) and significantly lower serum lipid levels compared to birds consuming the control diet. This could be taken to indicate that the leaf meal diets (and particularly the 6\% and 11\% GLM diets) contain both toxic compounds that are responsible for the haematological effects as well as species that are able to form complexes with cholesterol. Similar conclusions have been reported by Topping et al. (1980). The data presented in Table 9 show that some of the birds on the experimental diets had relatively high levels of abdominal fat. This may indicate that the leaf meal diets affect lipid synthesis and fat retention. It has been reported that saponins arrest growth by precipitating lipids or sterols in cell membranes.Table 9 further shows that the levels of high density lipoprotein (HDL), which is regarded as "good cholesterol", were highest in birds consuming the control diet and decreased as the amount of OLM in the diet increased; the lowest levels of HDL $(1.5 \mathrm{mg} / \mathrm{dl})$ occurred in birds consuming the $11 \%$ OLM diet. The lowest overall HDL levels $(1.33 \mathrm{gm} / \mathrm{dl})$ occurred in birds consuming the $1 \%$ GLM diet. There were significant $(\mathrm{p}<0.05)$ differences between the diets with respect to HDL levels. 


\section{SUMMARY}

The growing demand for and subsequent high cost of conventional animal feed ingredients in the tropics has created a need for sustainable alternatives. Alternatives deriving from natural resources that are indigenous to the region are particularly attractive for this purpose. In recent decades, the search for alternative feed resources has prompted renewed interest in the use of tropical plants as sources of nutrients for both ruminants and non-ruminants. However, any assessment of the potential of leaf meals in non ruminant nutrition requires a comparative review of their nutrient contents. Various groups have studied the potential of leaf meals from various plants, including Leuceanaleucocephala (Mecha and Adegbola, 1985; Vohra et al., 1972; D’Mello and Acamovic, 1989), Cajanuscajan (Udedibie and Opara 1998) and Manihotesculenta (Ravindran et al., 1993). While these trials yielded some promising results, the high fibre contents of the meals were consistently problematic. The most attractive property of leguminous leaf meals as feed components is their high crude protein content. While this property is often discussed at length, the associated drawback of a high fibre content (which is often equal to or greater than the protein content of the meal) is less widely emphasized. Fibre imposes severe limitations on the utility of leaf meals as animal feeds because it limits feed intake. The intakes for the leaf meal diets observed in this work were comparable to those for the control diet, although statistically significant differences $(p<0.05)$ remained. In previous studies on leaf meals, the intake declined linearly as the level of leaf meal in the feed increased (Udedibie and Opara, 1998; Okorie, 2006a,b). The hematological indices for the studied birds were generally quite low and were consistent with those reported by Gowda and Sastry, (2000), who observed reduced hemoglobin contents, erythrocyte counts and packed cell volumes in chickens that were fed diets containing $10 \%$ neem kernel meal by mass.

\section{TABLES}

Table 1: Proximate composition of the OLM and GLM meals (\%)

\begin{tabular}{|c|c|c|c|c|c|c|}
\hline & CP & EE & CF & Ash & NFE & DM\% \\
\hline OLM & 22.24 & 4.97 & 5.82 & 16.74 & 30.43 & \\
\hline GLM & 26.65 & 5.88 & 4.85 & 10.94 & 20.68 & \\
\hline
\end{tabular}

Source: Essiet (1999)

OLM = Ocimum leaf meal, GLM - Gongronema leaf meal, $\mathrm{CP}$-crude protein, $\mathrm{EE}=$ Ether extract, $\mathrm{CF}=$ crude Fibre, NFE = Nitrogen free extract DM = dry matter.

Table 2: Composition of the experimental diets

\begin{tabular}{|c|c|c|c|c|c|c|c|}
\hline Ingredient & $\mathbf{0 \%}$ & $\mathbf{1 \%}$ OLM & 6\% OLM & 11\% OLM & 1\% GLM & 6\% GLM & 11\% GLM \\
\hline Maize & 50.00 & 50.00 & 50.00 & 50.00 & 50.00 & 50.00 & 50.00 \\
\hline Leaf meal & - & 1.0 & 6.0 & 11.0 & 1.0 & 6.0 & 11.0 \\
\hline SBM & 16.0 & 14.0 & 12.0 & 10.00 & 14.00 & 12.00 & 10.00 \\
\hline GNC & 10.00 & 10.00 & 9.00 & 8.00 & 10.00 & 9.00 & 8.00 \\
\hline $\begin{array}{c}\text { Wheat } \\
\text { offal }\end{array}$ & 14.00 & 12.00 & 14.00 & 12.00 & 12.00 & 14.00 & 12.00 \\
\hline Fish meal & 5.0 & 5.0 & 4.0 & 4.0 & 5.0 & 4.0 & 4.0 \\
\hline Bone meal & 2.0 & 2.0 & 2.0 & 2.0 & 2.0 & 2.0 & 2.0 \\
\hline Oyster & 2.0 & 2.0 & 2.0 & 2.0 & 2.0 & 2.0 & 2.0 \\
\hline Salt & 0.25 & 0.25 & 0.25 & 0.25 & 0.25 & 0.25 & 0.25 \\
\hline Lysine & 0.25 & 0.25 & 0.25 & 0.25 & 0.25 & 0.25 & 0.25 \\
\hline Methionine & 0.25 & 0.25 & 0.25 & 0.25 & 0.25 & 0.25 & 0.25 \\
\hline $\begin{array}{c}\text { Trace } \\
\text { vit/min }\end{array}$ & 0.25 & 0.25 & 0.25 & 0.25 & 0.25 & 0.25 & 0.25 \\
\hline
\end{tabular}


Table 3: Calculated chemical compositions of the experimental diets

\begin{tabular}{|c|c|c|c|c|c|c|c|}
\hline Component & $\mathbf{0 \%}$ & $\begin{array}{c}\mathbf{1 \%} \\
\text { OLM }\end{array}$ & $\begin{array}{c}\mathbf{6 \%} \\
\text { OLM }\end{array}$ & $\mathbf{1 1 \%}$ OLM & $\begin{array}{c}\mathbf{1 \%} \\
\text { GLM }\end{array}$ & $\begin{array}{c}\text { 6\% } \\
\text { GLM }\end{array}$ & $\begin{array}{c}\mathbf{1 1 \%} \\
\text { GLM }\end{array}$ \\
\hline Crude protein & 18.66 & 19.06 & 18.90 & 18.71 & 18.60 & 18.90 & 19.08 \\
\hline Crude fibre & 4.68 & 4.74 & 4.86 & 4.93 & 4.72 & 4.85 & 4.90 \\
\hline Ether extract & 3.93 & 3.85 & 4.11 & 4.13 & 3.88 & 4.07 & 4.01 \\
\hline Ash & 5.33 & 5.14 & 5.12 & 5.21 & 5.23 & 5.11 & 5.15 \\
\hline Calcium & 1.73 & 1.72 & 1.74 & 1.72 & 1.73 & 1.74 & 1.73 \\
\hline Phosphorous & 0.57 & 0.58 & 0.57 & 0.57 & 0.58 & 0.57 & 0.58 \\
\hline l-Methionine & 0.30 & 0.30 & 0.31 & 0.32 & 0.30 & 0.33 & 0.31 \\
\hline l-Lysine & 0.77 & 0.76 & 0.77 & 0.75 & 0.76 & 0.78 & 0.77 \\
\hline ME(kcal/kg) & 2817. & 2873.65 & 2845.76 & 2811.44 & 2874.13 & 2798.14 & 2809.74 \\
\hline
\end{tabular}

\begin{tabular}{|l|c|c|c|c|c|c|c|l|}
\hline Index & $\mathbf{0 \%}$ & $\begin{array}{c}\mathbf{1 \%} \\
\text { OLM }\end{array}$ & $\begin{array}{c}\text { 6\% } \\
\text { OLM }\end{array}$ & $\begin{array}{c}\mathbf{1 1 \%} \\
\text { OLM }\end{array}$ & $\begin{array}{c}\mathbf{1 \%} \\
\text { GLM }\end{array}$ & $\mathbf{6 \%}$ GLM & $\mathbf{1 1 \%}$ GLM & SEM \\
\hline $\begin{array}{l}\text { Initial body } \\
\text { weight (kg) }\end{array}$ & 0.54 & 0.56 & 0.54 & 0.54 & 0.57 & 0.58 & $0.54^{* * *}$ & 8.62 \\
\hline $\begin{array}{l}\text { Final body } \\
\text { weight (kg) }\end{array}$ & $1.84^{\mathrm{ab}}$ & 1.88 & 1.97 & 2.04 & $1.86^{\mathrm{ab}}$ & $1.80^{\mathrm{ab}}$ & $1.72^{\mathrm{c}}$ & 0.032 \\
\hline $\begin{array}{l}\text { Body weight } \\
\text { gain (kg) }\end{array}$ & 1.30 & 1.31 & $1.43^{\mathrm{a}}$ & $1.50^{\mathrm{a}}$ & 1.28 & $1.22^{\mathrm{c}}$ & $1.17^{\mathrm{d}}$ & 0.025 \\
\hline $\begin{array}{l}\text { Daily weight } \\
\text { gain (g) }\end{array}$ & $35.1^{\mathrm{ab}}$ & $34.85^{\mathrm{ab}}$ & $38.96^{\mathrm{a}}$ & $39.76^{\mathrm{a}}$ & $33.77^{\mathrm{ab}}$ & $29.9^{\mathrm{c}}$ & $35.39^{\mathrm{ab}}$ & 1.21 \\
\hline $\begin{array}{l}\text { Feed intake } \\
\text { (g) }\end{array}$ & $120.3^{\mathrm{a}}$ & $120.8^{\mathrm{a}}$ & $120.4^{\mathrm{a}}$ & 114.2 & 120.10 & $119.8^{\mathrm{ab}}$ & $117.02^{\mathrm{ab}}$ & 2.34 \\
\hline $\begin{array}{l}\text { Feed } \\
\text { conversion } \\
\text { Ratio (\%) }\end{array}$ & $3.41^{\mathrm{ab}}$ & $3.44^{\mathrm{ab}}$ & $3.08^{\mathrm{a}}$ & $2.98^{\mathrm{c}}$ & $3.55^{\mathrm{ab}}$ & $3.97^{\mathrm{a}}$ & $3.30^{\mathrm{ab}}$ & 0.08 \\
\hline $\begin{array}{l}\text { Feed } \\
\text { efficiency } \\
(\%)\end{array}$ & $29.25^{\mathrm{ab}}$ & $29.04^{\mathrm{ab}}$ & $32.36^{\mathrm{a}}$ & $34.57^{\mathrm{a}}$ & 28.14 & 25.16 & $30.24^{\mathrm{ab}}$ & 2.01 \\
\hline $\begin{array}{l}\text { Mortality } \\
(\%)\end{array}$ & 0.00 & 0.00 & 0.00 & 0.00 & 0.00 & 0.00 & 0.00 & 0.00 \\
\hline
\end{tabular}

Table 4: Growth performance of the experimental diets

Means on the same row with different superscripted letters (abcd) are significantly different $(\mathrm{p}<0.05)$

\begin{tabular}{|c|c|c|c|c|c|c|c|c|}
\hline $\begin{array}{l}\text { Blood } \\
\text { parameter }\end{array}$ & $0 \%$ & $\begin{array}{c}1 \% \\
\text { OLM }\end{array}$ & $\begin{array}{c}6 \% \\
\text { OLM }\end{array}$ & $\begin{array}{l}11 \% \\
\text { OLM }\end{array}$ & $\begin{array}{c}1 \% \\
\text { GLM }\end{array}$ & $\begin{array}{c}6 \% \\
\text { GLM }\end{array}$ & $\begin{array}{l}11 \% \\
\text { GLM }\end{array}$ & SEM \\
\hline PCV $\quad(\%)$ & $17.16^{\mathrm{ab}}$ & $17.20^{\mathrm{ab}}$ & $14.83^{c}$ & $15.16^{\mathrm{c}}$ & $18.16^{b}$ & $20.16^{b}$ & $17.60^{\mathrm{a}}$ & 0.52 \\
\hline HB (g/100ml) & 6.46 & 5.35 & 5.00 & 5.01 & 5.63 & 6.61 & 5.33 & 0.71 \\
\hline МСНС & 3.01 & 3.08 & 3.36 & 3.26 & 3.16 & 3.23 & 3.20 & 0.64 \\
\hline TWBC $\left(X 10^{5}\right)$ & $3.60^{b}$ & 4.60 & 4.50 & $4.00^{\mathrm{ab}}$ & $5.30^{\mathrm{a}}$ & 4.30 & 4.50 & 1.34 \\
\hline Neutrophils & $49.60^{\mathrm{a}}$ & 43.30 & $50.60^{\mathrm{a}}$ & $49.80^{\mathrm{a}}$ & 44.60 & 49.60 & 47.10 & 1.04 \\
\hline Eosinophils & 2.40 & 2.30 & $2.50^{\mathrm{a}}$ & ABS & 2.30 & 2.00 & 2.50 & 0.11 \\
\hline Monocytes & 1.66 & 1.34 & 1.65 & 2.00 & 2.00 & 1.65 & $2.66^{\mathrm{a}}$ & 0.13 \\
\hline Basophil & $1.00^{\mathrm{ab}}$ & ABS & $\mathrm{ABS}$ & ABS & ABS & 2.00 & $1.00^{\mathrm{ab}}$ & 0.18 \\
\hline
\end{tabular}

Table 5: Hematological index data for the experimental birds

Means on the same row with different superscripted letters (abcd) are significantly different $(\mathrm{p}<0.05)$. $\mathrm{PCV}=$ packed cell volume, $\mathrm{HB}=$ Haemoglobin, $\mathrm{WBC}=$ white blood cell, $\mathrm{ABS}=$ absent . 
Table 6: Live and dressed weights of the experimental birds and their individual body parts (grams)

\begin{tabular}{|l|c|c|c|c|c|c|c|l|}
\hline Part & $\mathbf{0 \%}$ & $\begin{array}{c}\mathbf{1 \%} \\
\text { OLM }\end{array}$ & $\mathbf{6 \%}$ OLM & $\begin{array}{c}\mathbf{1 1 \%} \\
\text { OLM }\end{array}$ & $\begin{array}{c}\mathbf{1 \%} \\
\text { GLM }\end{array}$ & $\mathbf{6 \%}$ GLM & $\begin{array}{c}\text { 11\% } \\
\text { GLM }\end{array}$ & SEM \\
\hline Live weight & $1834^{\mathrm{b}}$ & $1683^{\mathrm{c}}$ & $1966^{\mathrm{a}}$ & $2033^{\mathrm{a}}$ & $1850^{\mathrm{b}}$ & $1800^{\mathrm{ab}}$ & $1716.6^{\mathrm{c}}$ & 39.88 \\
\hline $\begin{array}{l}\text { Plucked } \\
\text { weight }\end{array}$ & $1700^{\mathrm{ab}}$ & $1600^{\mathrm{bc}}$ & $1666^{\mathrm{c}}$ & $1900^{\mathrm{c}}$ & $1716^{\mathrm{b}}$ & $1650^{\mathrm{c}}$ & $1616^{\mathrm{ab}}$ & 42.43 \\
\hline $\begin{array}{l}\text { Dressed } \\
\text { weight }\end{array}$ & $1180^{\mathrm{c}}$ & $1083^{\mathrm{c}}$ & $1206^{\mathrm{b}}$ & $1360^{\mathrm{a}}$ & $1203^{\mathrm{ab}}$ & $1140^{\mathrm{c}}$ & $1140^{\mathrm{c}}$ & 2.75 \\
\hline $\begin{array}{l}\text { Breast } \\
\text { weight }\end{array}$ & 618.3 & 275.6 & 362.5 & 400.6 & 320.3 & 320.3 & 302.3 & 4.03 \\
\hline Shank & 45.3 & 45.0 & 50.6 & 49.0 & 45.0 & 45.3 & 42.3 & 1.31 \\
\hline Wing & 76.6 & 78.3 & 81.3 & 84.3 & 81.0 & 72.0 & 78.0 & 1.89 \\
\hline Neck & 78.0 & 69.6 & 65.6 & 67.0 & 65.6 & 62.0 & 68.6 & 2.11 \\
\hline $\begin{array}{l}\text { Thigh \& } \\
\text { drumstick }\end{array}$ & 202.3 & 200.6 & 232.6 & 236.6 & 209.6 & 202.6 & 196.0 & 4.70 \\
\hline
\end{tabular}

Means on the same row with different superscripted letters (abcd) are significantly different $(\mathrm{p}<0.05)$.

Table 7: Dressed weights of the experimental birds as a percentage of their live weight, and weights of individual body parts as percentages of their total dressed weight.

\begin{tabular}{|l|c|c|c|c|c|c|c|}
\hline \multicolumn{1}{|c|}{ Body part } & $\mathbf{0 \%}$ & $\begin{array}{c}\mathbf{1 \%} \\
\text { OLM }\end{array}$ & $\mathbf{6 \%}$ OLM & $\begin{array}{c}\mathbf{1 1 \%} \\
\text { OLM }\end{array}$ & $\begin{array}{c}\mathbf{1 \%} \\
\text { GLM }\end{array}$ & $\mathbf{6 \%}$ GLM & $\begin{array}{c}\text { 11\% } \\
\text { GLM }\end{array}$ \\
\hline $\begin{array}{l}\text { Dressed } \\
\text { weight }\end{array}$ & 64.34 & 64.34 & 61.34 & 66.89 & 65.02 & 63.33 & 66.41 \\
\hline Thigh & 17.22 & 18.52 & 19.28 & 17.39 & 17.42 & 17.77 & 17.19 \\
\hline Shank & 3.88 & 4.15 & 4.19 & 3.60 & 3.74 & 3.97 & 3.71 \\
\hline Wing & 6.49 & 7.22 & 6.74 & 6.30 & 6.73 & 6.31 & 6.84 \\
\hline Neck & 6.61 & 6.42 & 5.43 & 4.92 & 5.45 & 5.43 & 5.96 \\
\hline Breast & 52.39 & 25.44 & 30.05 & 29.45 & 26.62 & 28.09 & 26.51 \\
\hline
\end{tabular}

All values reported in this table are percentages.

Table 8: Organ weights for the experimental birds (\% of dressed weight)

\begin{tabular}{|l|c|c|c|c|c|c|c|c|}
\hline Organ & $\mathbf{0 \%}$ & 1\% OLM & 6\% OLM & 11\% OLM & 1\% GLM & 6\% GLM & 11\% GLM & SEM \\
\hline $\begin{array}{l}\text { Liver/gall } \\
\text { bladder }\end{array}$ & 3.19 & 1.90 & 2.59 & 2.06 & 2.75 & 2.55 & 2.27 & 2.70 \\
\hline Heart & 0.54 & 0.47 & 0.59 & 0.49 & 0.51 & 0.57 & 0.46 & 0.45 \\
\hline Spleen & 0.12 & 0.09 & 0.11 & 0.09 & 0.001 & 0.08 & 0.09 & 0.21 \\
\hline Gizzard & $2.54^{\mathrm{a}}$ & 2.43 & 2.20 & 2.14 & 2.43 & 2.38 & 2.38 & 1.38 \\
\hline
\end{tabular}

Means on the same row with different superscripted letters (abcd) are significantly different $(\mathrm{p}<0.05)$.

\section{CONCLUSION}

The results presented herein and in the related literature show that the leaf meals examined in this study are rich in nutrients, and particularly in protein. In addition, they have low contents of toxic substances such as tannins, phytins, and hydrocyanic acid. To properly evaluate the utility of the studied meals in poultry feeds, it will be necessary to expand the study to cover other nutrients and to determine the meals' contents of anti-nutritional factors such as oxalate, nitrite, saponins and alkaloids. This will facilitate the creation of optimized and safe leaf meal diets and will make it possible to accurately determine the nutritional value of the leaf meals. It is well known that the nutritional requirements of broiler chickens in the finisher phase of development are quite different from those of birds in the starter phase. This is because birds in the starter phase require nutrients both to grow and to develop from chicks to adults. 
There is a lack of data on the use of Ocimum and Gongronema leaf meals in poultry diets, particularly with respect to the appropriate amount of leaf meal in the diet and its content of anti-nutritional factors. It is therefore necessary to conduct further investigations into these meals, and particularly to characterize the anti-nutritional compounds they contain in order to identify the amount of meal that can safely be added to broiler diets.

Broilers in the finishing phase will ultimately be slaughtered and consumed by humans. It is therefore essential that their meat be of high quality, and so it will be necessary to study the properties of meat derived from broilers that have consumed diets containing leaf meals and demonstrate its fitness for human consumption. There is a global deficit of protein sources for monogastrics, and so it is likely that there will be an ongoing drive to exploit currently under-utilized crops in order to address this problem. The results presented herein suggest that OLM and GLM meals may have important but limited roles to play as sources of nutrients and xanthophylls. The major constraints on their use stem from their relatively high fiber contents, which were reflected in the greater gizzard weights of birds consuming OLM and GLM diets relative to controls. However, this may also have been partly due to the presence of anti-nutritional compounds in the meals, especially in the GLM. It should also be noted that the cholesterol-reducing effects of the leaf meal diets were probably due in part to the formation of insoluble complexes between cholesterol and the saponins present in the meals. The formation of such complexes in the digestive tracts of the chickens would prevent the absorption of saponins.

\section{RECOMMENDATIONS}

This work has demonstrated that the inclusion of Ocimumand Gongronemaleaf meals in the diets of broiler finisher birds did not affect their feed intake. However, the leaf meals did depress various hematological indices; this effect was especially pronounced for the $11 \%$ GLM diet. In addition, the scope for including these leaf meals (OLM and GLM) will be heavily dependent on the nature of the other protein sources used during the formulation of the diet. Further efforts should be made to identify vegetables, leguminous plants, and shrubs that could be used to prepare leaf meals for poultry nutrition; consideration should also be given to desert plants such as Yucca Schidigera and Quillajasaponaria, which are rich storehouses of phytochemicals with many useful and important functions in human and animal nutrition. To date, we have barely scratched the surface of the diverse biological effects of steroidal and triterpenoidsaponins and their potential for improving poultry nutrition. Based on the results presented herein, it is recommended that OLM and GLM should account for no more than $6 \%$ (by mass) of the diets of broiler finisher birds. Higher quantities could possibly be included if more sophisticated meal processing techniques are developed that can reduce the fibre and anti-nutrient contents of the meals. Therefore, further studies on the use and processing of Ocimumand Gongronema extracts and meals seem to be warranted.

\section{REFERENCES}

[1] Adeboye, O.C., Ogbe. O.F.D., Barnidele, J.F. (2003a) Ethnobotany: Indigenous leaf vegetables of South West Nigeria. Delpinoa45 :295-299.

[2] Adeboye, J.O and Iwalewa, O.J. (2003b). Analgesic, antipyretic, anti-inflammatory effects of methanol, chloroform, and ether extracts of vernoniacinerrealess leaf.J. Ethnopharmacol. 86 (20) : 229-234.

[3] Agale, B.M and Uko, O.J. (1989) Effects of season, sex and species differences on PCV of guinea and Domestic fowls in Sokoto, Nigeria.Vet. J.,19 : 95-99.

[4] Agricultural Research Council (ARC) (1975).The nutrient requirements of farm livestock, no. 1: Poultry. London, Agricultural Research Council.

[5] Anderson, J.O. and Warnick, R.E. (1989).Sequence in which essential amino acids become limiting for growth of chicks and rations containing cotton seed meal.Poult.Sci, $45: 84-89$.

[6] AOAC (1999).Official Methods of Analysis.Washington D.C., Association of Analytical Chemists.

[7] Atuahene, C.C., Don koh, A. and Nkansah-Dako. (1986). Effect of raw cotton seed meal on the performance, carcass characteristics and certain blood parameters of broiler chicken.J. Anim. Prod. Res. 6 (2) : 107-114.

[8] Ayodele, O. and Agboola, A. (1983).Some characteristics of moist Savannah soils and constraints on development with particular reference to Brazil and Nigeria.J. Biogeogr.15 (10): 11-18.

[9] Babatunde, G.M., and B.L. Fetuga (1976).Determination of the minimum crude protein requirement of broiler starter and finisher in the tropics.Nig. J. Anim. Prod. $3: 126-138$.

[10] Babady, N.E. and Ugochukwu, N.H. (2002). Antioxidant effects of Gongronemalatifolium in Hepatocytes of rat models of noninsulin dependent diabetes mellitus. Fitoterapia 73 (7-8) : 612-618.

[11] Bangbose, A.M. and Niba, A.T. (1998). The Nigerian livestock industry in the $21^{\text {st }}$ century. $3^{\text {rd }}$ Annual Conference of the Animal Science Association of Nigeria, pp. 84-87.

[12] Cheesbrough, M. (1987).Medical laboratory manual for tropical countries, $2^{\text {nd }}$ Ed. Oxford, Butterworth-Heinemann, pp. 514-518.

[13] Coles, M. J. (1977) Veterinary Clinical Pathology, $4^{\text {th }}$ Ed. Philadelphia, Saunders Co. 40-48

[14] Coring, T., Juste, and Lhoste, E.F. (1989).Nutritional regulation of pancreatic and biliary secretions.Nutr. Res. Rev. 2 : 161-180.

[15] D'Mello, J.P.F. (1992). Chemical constraints to the use of tropical legumes in animal nutrition.Anim. Feed Sci. Tech.,38 : 237-261.

[16] D’Mello, J.P.F. and Acamovic, T., (1989) Leucaenaleucoephala in poultry nutrition: a review.Anim. Feed Sci. Tech. 26 : 1-28. 
[17] Ekenyem, B.U. (2006). An assessment of Ipomoea asarifolialeaf meal as a feed ingredient in grower pig diet.Pak. J. Nutr. $5: 39-42$.

[18] Esonu B.O., Iheukwumere, F.C., Emenalom, O.O., Uchegbu, M.C., and Etuk, E.B. (2002). Performance, nutrient utilisation and organ characteristics of broilers fed Microdesmispuberula leaf meal. Livest.Res. Rural Dev. 14 (6). Retrieved on June 10, 2013, from http://www.lrrd.org/lrrd14/6/eson146.htm

[19] Gbile and Adesina, D.F. (1986).Ethnopharmocology: Biobehavioural Approaches in the Anthropological study of Indigenous Medicines. Adapted from Nina L. Etkin, Ann. Rev. Anthropol.17 (1988) : 23-42.

[20] Gowda, S.K. and V.R.B. Sastry (2000).Neem(AzadirachtaIndica) seed cake in animal feeding - scope and limitations Review.Asian-Australas. J. Anim. Sci., 13 : 720-728.

[21] Herbert, U. (1998). Reproductive performance of rabbit does fed diets containing Gliricidia leaf meal from conception through weaning of kits. Nig. J. Anim. Prod., $25: 163-168$.

[22] Hurwitz, S., Weiselberg, M., Eisner, U., Barton, I., Riesenfeld, G., Sharvit, M. Niv, A., and Bornstein, S.W. (1980).The energy requirements and performance of growing chickens and turkeys as affected by environment temperature.Poult. Sci. 59:229-229.

[23] Igile, G.O., Oleszek, W., Jurzusta, M., Burda, S., Fafunso, M. and Fasanmade, A.A. (1994). Flavonoids from Vernoniaamygdalina and their anti-oxidant activity. J. Agric. Food Chem. 43 : 2445-2448.

[24] Igile G.O., Pizza, C. and Leszek, W. (1986) Saponins and Phenols of Yucca SchidiferaRoezl: chemistry and bioactivity.Phytochem. Rev. 4 (2-3) 177-190.

[25] Jain, N.C (1986). Veterinary haematology, $4^{\text {th }}$ Ed. Philadelphia, Lea and Febiger.

[26] Jensen, J., Robbins, K., Ryan, K.J., Brewer, M.S., McKeith, C. (1997) Consumer attitude towards meat and acceptability of enhanced beef.Meat Sci. 65 (2) : 721-729.

[27] Lindsay, D.B. (1977). The effects of feeding patterns and sampling on blood parameters.Occasional Publication No. 1, British Society for Animal Production. (ed D Lister). pp. 99-120.

[28] Mecha, I. and Adegbola, T.A. (1985).Chemical composition of some southern Nigerian forage eaten by goats. In: Le Hhouerou, h.N. (Ed). Browse in Africa: the current state of knowledge. Addis Ababa, International Livestock Centre for Africa.

[29] Miller, T.B. and Rains, B.A. (1963).The nutritive value and agronomic aspects of some fodders in Northern Nigeria. J. Br. Grassl. Soc. 19 : $158-167$.

[30] Mishra, M., Singh, I. and Sahoo, G. (1977).Effect of feeding Gliricidia maculate leaf meal on the performance of white leghorn chicks.Ind. J. Poult. Sci. $12: 17-21$.

[31] Mitruka, B.M. and Rawnsley, H.N. (1977): Clinical biochemical and hematological reference values in normal experimental animals. New York, Masson.

[32] Ndon, B.A., and Essien, A.I., (1987) The establishment of local browse species in comparison with Leucaena sp. And Glicidia sp.Proceedings of the symposium on browse and small ruminant production in Southeastern Nigeria at the International Livestock Centre for Africa (ILCA), humid zone program, Ibadan, Nigeria.

[33] Odunsi, A. A., Ogunkele, M. O., Alagbe, O. S. and Ajani, T. O. (2002) Effects of feeding Gliricidiasepium leaf meal on the Performance of WAD Nig. J.Anim. Prod. 28:61-64

[34] Okafor, J.C, Okolo, H.C. Ejiofor, M. (1996). Strategies for enhancement of utilization \& potential of edible woody species of South-Eastern Nigeria, in: The Biodiversity of African Plants, pp. 684-695. The Netherlands, Kluwer.

[35] Okeudo, N. Okoli, I.C. and Iqwe, G.O. F (2003).Hematological characteristics of dusks (carina moschata) of South Eastern Nigeria.Tropicultura $21: 61-65$.

[36] Okoli, I.C. ,Ebere, C.S., Emenalom, O.O., Uchegbu, M.C., Reynolds, L. and Atta-Krah, A.N. (1987). Browse and indigenous livestock production paradigms revisited. 111: An assessment of the proximate values of most preferred indigenous browses of southeastern Nigeria. Anim. Prod. Investig. 4 : 99-107.

[37] Okorie, K.C. (2006a). Evaluation of leaf meals from Pentachlethramacrophylia, Jacaranda mimosifolia and Macunapruriensas feed ingredient in poultry diets, $P h D$ Thesis, Fed.Univ. of Tech., Owerri, Nigeria.

[38] Okorie, K.C. (2006b). Aspects of the haematology and serum biochemical indices of finisher broilers fed Jacaranda mimosifolialeaf meal diets. J. Anim. Prod. Adv.2 (2) : 113-117.

[39] Olomu, J.M. and Offiong, S.A. (1980). The effects of different protein and energy levels and time of change from starter to finisher ration on the performance of broiler chickens in the tropics. Poult. Sci. 59: 828-835.

[40] Oluyemi, J.A. and Roberts, F.A. (1979).Poultry production in warm climates.( $1^{\text {st }}$ ed.), London, MacMillan.

[41] Oji U.I. and Isilebo, J.O. (2000) Nutrient characteristics of selected browse plants of the humid tropics.Proceedings of the $25^{\text {th }}$ annual conference of the Nigerian Society for Animal Production.

[42] Omekam, V.N., (1994) Studies on nutritional and health implications of dietary inclusion of dried poultry waste for broilers. $M$. Sc. Thesis, Federal University of Technology, Owerri, Nigeria.

[43] Onyeyili, P.A., Egwu, G.O., Jibike, G.I., Pepper, D.O., and Ohaegbulem, J.O. (1992) Seasonal variation on haematological indices in the grey-breasted Guinea fowls.Nig. J. Anim. Prod., 18 : 101-107

[44] Onwudike, O.C. (1995). Use of the legume tree crops Glinicidiasepium and leucaenaleucocephalaas green feeds for growing rabbits.Anim. Feed Sci. Tech.,51 : 153-163.

[45] Ozimek, A., Lanchman, O., (1995a): The influence of lipid on exocrine pancreatic secretions in pigs. Asian-Australas. J. Anim. Sci. $13(5)$ : 711-719.

[46] Ozimek, L., Sauer, W.C., Kozikowski, V., Ryan, J.K., Jorgensen, H. and Jelen, P., (1995b). Nutritive value of protein extracted from honey bees. J. Food Sci., 50 : 1327-1332.

[47] Ravindran, V. (1993). Cassava leaves as animal feed: Potential and limitations. J. Sci. Food Agric., 8 : 141-150.

[48] Reynolds, L. and Atta-Krah, A.N. (1987) Browse use and small ruminant production in southeastern Nigeria.Proceedings of the symposium at the International Livestock Centre for Africa (ILCA), humid zone program, Ibadan, Nigeria.

[49] Snedecor,G.W. and Cochran, W.G. (1978). Statistical Methods, $6^{\text {th }}$ ed. Ames, Iowa, Iowa State University Press.

[50] Steel, R.G.D. and Torrie, J.H. (1980).Principles and procedures of statistics, $2^{\text {nd }}$ ed. London, McGraw-Hill.

[51] Takada, K., Nakazato, T., Ono, K., Honda, H., and Yamena, T. (1980). Feeding value of leaf meal of Acacia on poultry feed. Jap.Poult. Sci. J., 17 : 229-305.

[52] Taiwo, A.A., Adejuyigbe, A.D., Talabi, E.O., and Okumakuma, G (2002). Seed meal based diets on the performance and haematology of reared rabbits. Proceedings of the $8^{\text {th }}$ Annual Conference of the Animal Science Association of Nigeria (ASAN), Federal University of Technology, Minna, Niger State, Nigeria, pp.83-86.

[53] Topping, D.L. Storer, G.B. Illman, G.D., Oakefall, R.J. and Weller, R.A. (1980) Effect of dietary saponins in faecal bile acids a neutral sterol, plasma lipids and lipoprotein turnover in the Pig. Am. J. Clin. Nutr.33 : 783-786. 
[54] Udedibie, A.B.I. and Opara, C.C. (1998).Responses of growing broilers and laying hens to the dietary inclusion of leaf meal from Alchorniacordifolia. Anim. Feed Sci. Tech., 71 (1-2) : 157-164.

[55] Uko, O.J. Ataja, A.M, and Tanko, H.B. (2000). Weight gain, haematology and blood chemistry of rabbits fed cereal offals. Sokoto J. Vet. Sci. 2 (2) : 18-26.

[56] Umoh, B.I., Okon, B.I. James, E.S. (2003). Effect of feeding varying levels of Microdemispuberula and Alchorneacordifolia on the body size and carcass component of West African dwarf goats. Glob. J. Agric. Sci. 3 (1 \& 2) : 45-51.

[57] Vohra,P. Herrick,r.B. Wilson,W.O. and Scopes, T.D. (1972). The use of (Leuceanaleucocephala) in the diets of laying hen chickens and laying quail. Philipp. Agric. Sci., $56: 104-133$.

[58] Yu, J.,Feng, J., Ma, W., Xu, Y., Wang, Y., and Liu, J., (2007). Effects of iron glycine chelate on growth, haematological and immunological characteristics in weaning piglets. Anim. Feed Sci. Tech., 134 (3-4) : 261-272. 